Meta

Journal des traducteurs

Translators' Journal

\title{
The Soviet Translation: Romanian Literary Translators after World War Two
}

\section{Sean Cotter}

Volume 53, numéro 4, décembre 2008

URI : https://id.erudit.org/iderudit/019650ar

DOI : https://doi.org/10.7202/019650ar

Aller au sommaire du numéro

Éditeur(s)

Les Presses de l'Université de Montréal

ISSN

0026-0452 (imprimé)

1492-1421 (numérique)

Découvrir la revue

Citer cet article

Cotter, S. (2008). The Soviet Translation: Romanian Literary Translators after World War Two. Meta, 53(4), 841-859. https://doi.org/10.7202/019650ar
Résumé de l'article

Cet article décrit à la fois le discours et la pratique de la traduction littéraire pendant la période de la colonisation de la Roumanie par les Soviétiques. La traduction est un objet idéal d'étude du processus culturel et politique de cette époque, à cause de la manière avec laquelle la colonisation soviétique a privilégié la transformation de la nation à travers sa langue. Le nouveau régime a poursuivi une politique dans laquelle la langue roumaine subissait des transformations étrangères, ce qui crée des conditions favorisant une pratique réfractaire à l'intégration. Ce modèle renverse la compréhension des politiques culturelles de la traduction, comme elle a été expliquée par Lawrence Venuti. Le présent travail se concentre sur une traduction spécifique : la version de Faust publiée en 1955 par Lucian Blaga. Quand on regarde le rôle de la traduction dans la colonisation soviétique de la Roumanie, on peut mieux comprendre comment la culture, la langue et le pouvoir se rejoignent pour constituer des formes uniques de domination tout autant que de résistance.
Ce document est protégé par la loi sur le droit d'auteur. L'utilisation des services d’Érudit (y compris la reproduction) est assujettie à sa politique d'utilisation que vous pouvez consulter en ligne.

https://apropos.erudit.org/fr/usagers/politique-dutilisation/ 


\title{
The Soviet Translation: Romanian Literary Translators after World War Two
}

\author{
SEA N COTTER \\ The University of Texas at Dallas, Dallas, U.S.A. \\ sean.cotter@utdallas.edu
}

\begin{abstract}
RÉSUMÉ
Cet article décrit à la fois le discours et la pratique de la traduction littéraire pendant la période de la colonisation de la Roumanie par les Soviétiques. La traduction est un objet idéal d'étude du processus culturel et politique de cette époque, à cause de la manière avec laquelle la colonisation soviétique a privilégié la transformation de la nation à travers sa langue. Le nouveau régime a poursuivi une politique dans laquelle la langue roumaine subissait des transformations étrangères, ce qui crée des conditions favorisant une pratique réfractaire à l'intégration. Ce modèle renverse la compréhension des politiques culturelles de la traduction, comme elle a été expliquée par Lawrence Venuti. Le présent travail se concentre sur une traduction spécifique: la version de Faust publiée en 1955 par Lucian Blaga. Quand on regarde le rôle de la traduction dans la colonisation soviétique de la Roumanie, on peut mieux comprendre comment la culture, la langue et le pouvoir se rejoignent pour constituer des formes uniques de domination tout autant que de résistance.
\end{abstract}

\begin{abstract}
This article describes the discourse and practice of translation during the Soviet colonization of Romania. Translation serves as an ideal object for the study of this cultural political process, because Soviet colonization emphasized the transformation of a nation through language. The new regime pursues a policy of foreignizing Romanian, creating the conditions for a resistant practice of domestication. This model reverses our common understanding of cultural politics of translation, exemplified by Lawrence Venuti. I focus on one actual translation: Lucian Blaga's 1955 version of Faust. By looking at the role of translation in the Soviet colonization of Romania, we can better understand how culture, language, and power come together, creating unique forms of both domination and resistance.
\end{abstract}

\section{MOTS-CLÉS/KEYWORDS}

culture, literary translation, resistance, Romania, Soviet translation

The role of translation in Soviet colonization of Romania at once confirms and reverses our common readings of translation, power, and resistance. The literal practice of translation was essential to the metaphorical translation of the country into Soviet control during the beginnings of Communist Party control of Romania - that is, the Soviet military presence (1944 to 1958), the Petru Groza government (1945 to 1947), and the "internationalist" Gheorghe Gheorghiu-Dej period (1948 to 1965) that preceded the nationalist, "maverick" period of better-known Nicolae Ceauşescu. We may call the early communist period, with only moderate irony, a Golden Age of Romanian translation. The new Romanian regime initiated a massive project of translation, both technical and literary, and coupled it with a politics of language and an ideology of reading, all of which was meant to bring the new Romania into line 
with the Soviet Union. The translation project was the cultural counterpart of power consolidation and national modernization, a golden age meant to usher in the luminous dawn of communism. In this sense, then, the Romanian case confirms our common understanding that translation is a key site for reading the intersections of cultural change, language, and power.

The alignment of foreignizing translation and hegemony, however, reverses the assumption that foreignizing is a strategy of resistance to power. In 1940s and 1950s Romania, colonization strove to Sovietize Romania, that is, to foreignize Romania from itself. ${ }^{1}$ Translations from Soviet socialist realist texts were meant to import the "soul of the new socialist," to move the Romanian reader from his domestic subjectivity to one in line with the ideology of the Soviet Union. This literature should inculcate the attitudes and ideas most useful to the process of colonization, and even some actual practices of modernization. This program is oriented toward not only content but also language. The Romanian language should change to register interference from Russian: Latinate vocabulary should become Slavicized, syntagms of official speech should be reproduced word-for-word, and Romanian grammar should be violated to reproduce Russian constructions. Even that literature not translated from Russian should, therefore, be translated into a Russofied Romanian. Furthermore, works that are not translations should sound like translations, because their Romanian has been foreignized. The name of the country would be changed from "România," spelled with a Latin character, to "Romînia," spelled with a Slavic character. The imposition of Soviet power followed a thoroughly foreignizing strategy, while domestication was a possible strategy of resistance.

This pair, foreignization and domestication - as well as the associations foreignization and resistance, and domestication and imperialism - come from Lawrence Venuti's The Translator's Invisibility. His idea that "Foreignizing translation is a dissident cultural practice" is the keystone of both his translation readings and his progressive, late-Marxist ethics (Venuti 1995: 148). His book argues the utility of foreignized translation for less-powerful cultures to resist the more-powerful. It is difficult to understate the influence his book has had on Translation Studies since its publication in 1995. While his more recent work has tended to substitute "fluency" for "domestication" and "archaism" for "foreignization," this shift has not marked a broad change in his ideas about language. Invisibility remains the best introduction to his widely repeated arguments connecting foreignizing translation practice and dissident cultural politics. The widespread use of the domestication / foreignization binary, however, does not mean it is widely useful. His book cannot account for the situation of Romania under Soviet colonization. His assumption of the inherently resistant ideology of foreignized translation leads him to uncomfortable positions when read against the context of Eastern Europe:

Foreignizing translation signifies the difference of the foreign text, yet only by disrupting the cultural codes that prevail in the target language. In its effort to do right abroad, this translation method must do wrong at home [...]. (Venuti 1995: 20)

Indeed, the translator who does right abroad, that is, by Soviet standards, does wrong at home to Romania and Romanian. The more powerful disrupts the culture of the less powerful. If we apply Venuti's terms to Eastern Europe, a context Venuti never addresses in his otherwise far-ranging book, we find Venuti arguing the case 
of empire. I invoke his work here, but only in passing do I want to suggest a critique of his ideas of ideology and language. The domestication / foreignization dichotomy in Invisibility has already been justly criticized for its rigidity and its reductiveness, and reversing its moral polarities does not make it more complicated. ${ }^{2}$ I use "foreignization" for a more surprising reason: it marks a logic of translation ideally suited to the Romanian case. Invisibility thinks about translation like a Stalinist. As such, this term is well-suited to describe the logic of the 1940s and 50s Romanian state translation project.

This article describes the logic of translation underlying the Soviet colonization of Romania. I read the foreignizing structures recorded in the language manual Iorgu Iordan delivered to the Central Committee in 1949, a remarkably candid analysis of the state's language politics. His work shows the connections between a Russofied Romanian and the demonstration of allegiance to the Soviet Union and the interpellation of others into that allegiance. This same logic organizes the discourse surrounding the project of translating thousands of titles of Soviet literature. These titles are intended to bring the reader into Soviet ideology, and a "good" translation is one which takes the reader into the Soviet reality. The translation into Romanian leads to the translation of Romania into the Soviet Union.

The most important feature of the state's foreignizing strategy, however, is its unintended enabling of resistance through domestication. To adopt domestication as a strategy is to agree that translation should be defined by its relative foreignization or domestication. Some Romanian translators find it useful to adopt this much of the state's ideology of translation. Because this resistance makes use of the same logic of translation as the hegemonic power, it can find a voice within state-controlled public discourse. I spend the last third of this article detailing the ways in which two authors, Alexandru Philippide and Lucian Blaga, appeal to Romanianness in translation. Their domestication strategies find a point of dialog with the otherwise monolithic state. I focus on one actual translation: Blaga's 1955 version of Faust. The strategy of domestication within the translation shows Blaga staging resistance, and the history of its reception gives a glimpse of the possible power of that performance.

This article has the limited scope of showing the conjunction of a logic of colonization and foreignized translation. For this reason, I do not give much detail on the actual political history of Romania's relationship to the Soviet Union, or the actual effectiveness of resistance strategies. Both of these occurred with all the variety and complication that one would expect, and that history is more diverse than either Invisibility or the Soviet-Romanian state's terms would allow me to describe. ${ }^{3} \mathrm{My}$ analysis is meant to accomplish two ends: first, to show the importance of this translation project to the beginnings of Romanian communism, and second, to demonstrate the value of contextual readings of cultural logic for Translation Studies. I hope to prove that, in the minds of the important Romanian historical actors, translation is the most important metaphor for and practice of social change. In the minds of Translation Studies scholars, the analysis of translation needs conceptual terms grounded in historical knowledge. By looking at the role of translation in the Soviet colonization of Romania, we can better understand how culture, language, and power come together, creating unique forms of both domination and resistance. 


\section{The foreignized tongue of the state}

Iordan's 1949 study "Russian Influences on the Romanian Language" evaluates the changes in Romanian since the arrival of the Soviets five years earlier. ${ }^{4}$ Iordan's 72 page text provides a conceptual model of the politics of translation and its role in the interpellation of Romania into the Soviet empire. He defines an ideology of language use intended, on the one hand, to lead the Romanian language and people into alignment with the Soviet Union. On the other hand, the language use will demonstrate, to the Soviet Union, Romania's acceptance of that alignment. A foreignized Romanian accomplishes both goals. The mechanism of this transformation through language is, naturally, translation. The more that Romania translates from Russian, the more Romania is translated into the Soviet Union. Iordan imagines that translation will have such an effect that Romania's cultural and geographical specificity will disappear. Those who were Romanians will speak to each other in Russian. By drawing the languages closer, the translator will work toward the unification of Romania and the Soviet Union. Iordan foresees a future in which the need for translation has withered away:

The situation will last a bit longer, until Romanian knowledge of Russian will achieve a quantitative and qualitative spread, enough to make it fluently usable in its spoken aspect, as much as in relations among people as in, especially, relations with speaking subjects whose mother language is Russian. ${ }^{5}$ (Iordan 1949: 17)

The everyday use of Russian, as a language of preference for Romanians: this is the teleology of literary translation in 1950s Romania. This document is presented to the Central Committee and then published with that body's authorization. Iordan is a member of the newly reformulated Romanian academy, and he has a reputation as a linguist and, more importantly, as a communist which dates from before the war. In the ensuing decade, he will move in and out of the leadership of the Linguistics Institute of the Academy of the Romanian People's Republic. ${ }^{6}$ His status and the approval of the Central Committee elevate this document from a description of the state of the language to a policy statement on the intended direction of its development.

Iordan adduces a list of words, all new, he says, in the five years since the entry of the Soviet army, evidence of widespread Romanian support. His examples all come from official speeches by party members and the party newspaper (a fact which might trouble his definition of "widespread"). He attributes this extensive list of current phrases to translation in every case. He cites a Russian original, also always from official utterances - Lenin, Stalin, etc. - to mark these new words as translations, and therefore to mark translation as a sign of Romania's support of the Soviets. Most of these words are governmental, economic, and military terms. Iordan pays special attention to the ways in which new Russian words in Romanian alter former translation practice. Iordan applauds the pull these Russofied phrases exert over translators, as direct borrowings of Russian words supersede old Romanian translations. For example, "narodnik," writes Iordan, "was formerly translated by populist" but is now translated by the Russian calque (43). Translators, in Iordan's vision, are leaders in the ideological transformation of Romania. Language practice is public policy. These linguistic developments are meant to demonstrate, to both Soviet and Romanian readers, the power and stability of the new regime. 
Iordan's strongest example of the politics of foreignized Romanian comes in his discussion of personal pronouns. Like in Spanish, Romanian verb conjugations are sufficiently varied that the pronoun is usually not necessary. Iordan observes, however, that since the Soviet occupation began, Romanian official speech has used the personal pronoun "where we are not used to finding it." Iordan's explanation of this adaptation goes beyond linguistic influence and arrives at the baldly ideological:

The people of our party are fighters. They always have in sight the adversaries and foes of the working class everywhere. These enemies are ever-present, if not physically, as is often the case, then surely through their actions in every moment, aimed against the permanent interests of the workers, of honest people everywhere. This continual presence of class enemies, expressed in language through "you" or "they" (even if these words never appear in the article or speech), leads inevitably to the frequent use of we where, strictly grammatically speaking, this pronoun would be pointless. We opposes, with firmness and violence, you or they, and its frequent appearance gives the impression of repeated blows against the adversary. ${ }^{8}$ (Iordan 1949: 17)

The pointless pronoun is a key feature of foreignized Romanian. It does nothing for the Romanianness of the sentence; rather, it makes the sentence more awkward. In this way, it shows the speaker's commitment to battle along Party lines. The pointlessness of the pronoun proves the speaker's sincerity. The speaker wants to show his willingness to be foreignized, his pro-Soviet sacrifice.

The pointless pronoun, more importantly, is intended to change the speaker's Romanian audience. The commitment to "we" works best when the enemy is not present. In one sense, "we" best opposes class enemies when a "you" or "they" is not physically present to evidence the effect of the repeated blows. In a more profound sense, the grammatical absence of these enemies allows the speaker's audience to enter the language's ideology. Iordan explains this logic with a quote from the leader of the Romanian Communist Party:

Take a very eloquent example: "We do not educate our youth in the spirit of hooliganism..." (Gh. Gheorghiu-Dej). After every passage with we, you or they comes automatically into the mind of the reader, who completes the thought of the author, according to his intentions: we do not educate our youth as you do (or as they do $)$ [...]. ${ }^{9}$ (Iordan 1949: 64)

The repetitions of "we" and the absence of "you" or "they" draw the listener into the ideology of foreignized Romanian. The listener shows his identification with the "we" by chiming in with the name of the addressee, volunteering a piece of foreignized speech in his own mind. The politics and practice of this language accomplish the same end as the literal practice of translation, which draws Romania toward the Soviet Union. The result of translation from Russian into Romanian is the interpellation of Romania into Soviet ideology, as the Romanian speaker translates his consciousness into the Soviet. The audience must adopt the "we"; it holds, in Mao's phrase, the butt of the rifle. The only other position this language allows is at the end of the barrel, marked "you."

Iordan shows us more than a particular case of the general practice of politicizing language in the Soviet colony. He also shows us translation as the end of politicized language. That is to say, the goal of interpellating people into the State language is to move them into translation. Translation is a middle state, between Romanian 
and that language's eventual replacement by Russian. To move into translation is to move away from a nationalist allegiance to one's native language. Foreignized translation is obedience. Rather than translating Russian into Romanian, the lexical changes Iordan presents show that Romanian and Romania are being translated into Russian terms, into the Soviet empire. While the relationship of these two countries occurred with all the variation and complication one would expect, the rhetorical simplification imposed by the Soviets and Soviet-supported Romanians like Iordan reduces the options to only two. Either you are part of "we" or part of "them"; either you are foreignized or you resist.

The debates on translation from the 1950s center on this opposition between a Romanian marked as domestic and a Romanian marked as foreign. The discourse around and use of translations in the 1950s shows that what Iordan describes in his treatise is more than translation as a metaphor for transformation or translation as a mechanism of political rhetoric. Translations can have as literal an effect as the instruction in work methods for a prison labor camp. They also, despite the intentions of the state and because of the objective conditions of the country, allow translation to become a site of resistance to Sovietization. Both the new Romanian state and its resistors agree on the terms of conflict: foreignized Romanian, created through translation, intended to transform Romanian subjectivity.

\section{The golden age of literary translation}

Criticism of literary translation in 1950s Romania - as found in journal articles, books chapters, reviews, and newspaper debates - operates within the ideological rubrics we know from Iordan. The metaphorical translation of Romania into the Soviet system is literalized through Romanian translations of Soviet books. The scale of the former transformation is reflected in the quantity of the latter. In 1951, Mihai Novicov reports that one press, "The Russian Book,"10 had published 856 translations from Russian and 270 translations from other languages of the Soviet Union, in the first six years of its existence (Novicov 1951: 200). His figures are probably only somewhat inflated. Official statistics, published beginning May of 1952, are close to or above the mark of 187 translations per year. A review of Buletinul bibliografic al camerei carții din Republica Populară Romană (1952-1956) and Bibliografia Republicii Populare Române (1957-1959) shows the number of translations published in this period (1688) exceeds the number of original Romanian works (1598), with almost one-third of the translations coming from Russian (1007). ${ }^{11}$ These figures include only literary works. Were we to include the number of technical manuals, textbooks, Marxist-Leninist pamphlets and books, etc. being translated from Russian, the number would far outdistance the corresponding works in Romanian. Literary translations were predominantly from Soviet literature, but they included classical Russian literature, and they quickly expanded to encompass certain Western figures as well: Rabelais, Shakespeare, Goethe. The number and quality of literary translations produced, from a variety of languages, makes this period a kind of golden age of Romanian literary translation.

The idea of a new age of literary translation is current in the discourse of translation. In official speech and writing, the Soviet period marks a new period in all modes of production, including translation. Cezar Petrescu claims a particular 
importance for translation as Romania finds itself at the beginning of the communist period: "Writers are especially preoccupied by translations in the heroic age of beginnings" (Petrescu). ${ }^{12}$ In this new context, translation "has taken an unusually large upsurge, as part of the cultural revolution" (Anonymous 1954a: 218). ${ }^{13}$ An important part of the discourse of this new age is the idea that the previous age of translation was terrible. The most widely used definition of a "bad" translation is both chronological and economic: any translation published before 1944 was done for profit and cannot be good:

Until 23 August $1944 \ldots$ the race for the greatest gain possible - the unforgiving fundamental law of capitalism - was, seemingly naturally, the fundamental law of publishing in bourgeois Romania, as well. This law urged publishers to translate into Romanian according to their bias and in large quantities, exactly the most decadent pearls of the West.... ${ }^{14}$ (Botez 1954)

The Western content of these books makes them "decadent" and signals the poor quality of the translations themselves:

[...] the road which almost without exception has lead to an industry of literary offal, in the countries of the capitalist world, where poor quality goods were and are sold with alluringly glittering labels, like canned food, with the ever-present danger of food poisoning. ${ }^{15}$ (Petrescu 1954)

The new age of Romanian literary translation is inaugurated specifically to change the means of translation production to introduce the right kinds of books, translated the right way. In August 1945, an unsigned article in the state newspaper Scânteia announces the new translation program, intended to change "the commercial attitude toward translation and the unfamiliarity with the criteria a translator, and implicitly a translation, must fulfill" (Anonymous 1945). ${ }^{16}$ The two go hand-in-hand: a commercial attitude means that the translator and translation do not meet expectations. A bad translation, therefore, comes from a capitalist system and cannot help but represent that world's poisonous decadence.

The new program announced in this article is intended to introduce good translation practices into Romania and therefore to introduce progressive culture. The article states that, alongside The Russian Book, a new state publishing house (the future State Publishing House for Literature and Art [ESPLA $]^{17}$ ) is being created to respond

by means of books, to the burning thirst for knowledge of great Romanian strata, who have thus the privilege of contact with the culture of progressive countries and in the first place with the rich and active culture of the Soviet Union. ${ }^{18}$

The qualifications on culture (only progressive countries and the Soviets) shows the ideology of this translation project. This project will translate not just literature but consciousness. The distinction I made earlier between literature and technical manuals, therefore, is not always clear. While the former carries more high-culture status, it is to be used like the latter: as a series of instructions for both the creation of the new person's soul and also the industrialization of his country. With minor exception, the discourse of translation in 1950s Romania focuses on the translation of works from Russian and Soviet literature and emphasizes the need for Romania to learn from the more advanced Soviet Union the correct implementation of socialism. An unsigned article in New Age states that translations of Soviet literature 
have the very important role of educating our entire working people in the spirit of communist ideals, of incarnating great examples of heroism and creation, of upsurged work in the service of the country, of patriotism and of the defense of peace, examples which help in the work of constructing socialism in our country. ${ }^{19}$ (Anonymous 1954b)

This passage gathers together many of the tropes of the rhetoric of the new regime: the construction of socialism, the defense of peace, the working people, and the heroic example of the Soviet Union. It demonstrates the educational role that translations of Soviet literature must play for Romanians. It also defines a "good" translation. The more accurately a translation communicates the "realities" of the Soviet Union, as defined in party discourse, the better it is. A clear example comes in Veronica Porumbacu's description of her trip to a Soviet textile factory. She is surprised to find there a figure that she recognizes, "a little girl, about 18 years old, who ran an entire machine shop by herself. ...Where had I seen her before? Only later, I remembered the translation in 'Littérature soviétique' of a poem by Scipaciov" (Porumbacu 1954: 375). ${ }^{20}$ Her journey to the source of the literature confirms that the translation has transmitted the necessary lesson. This context also informs Tudor Vianu's recommendations for translation:

A translation should not only bring great foreign writers closer to us, but it should also bring us closer to their world. A masterful translation opens new perspectives on a world unknown to us; it makes chords that had never vibrated resound in our soul. A translation should be a journey in a foreign country. ${ }^{21}$ (Vianu 1956: 275)

"Journey" is not a neutral word in a time of passport control. It suggests the official privilege of trips like those Vianu made while ambassador to Belgrade, or a sojourn in the Soviet Union like that described by Porumbacu. The intention to bring the domestic closer to the world of foreigners is one often found, albeit in less elegant formulations, in this discourse of translation theory. The official task of the Romanian translator is, by translating from Soviet literature, to lead Romania into the world of the Soviet Union. The Golden Age of Romanian literary translation is meant to create the luminous future of Soviet communism. ${ }^{22}$

This discourse of translation I have recorded here is, of course, more than a style of speech. Literary policy under the new Romanian regime is public policy, and the literary works so promoted have consequences for more than the soul of the colonized Romanian. Mihai Novicov, a senior member of the Writers Union, stresses this role in his address at the 1951 writers' congress:

Among the means through which our working people raise up and valorize the example of the Soviet Union, translations from Russian literature and Soviet literature have a place of honor.

Soviet literature is the most advanced literature in the world today, in the first place because it mirrors the most advanced reality - socialist reality. [...] Soviet literature shows us how, in the fire of this fight [toward the luminous dawn of communism] a new mentality has been built, a new, superior person has been born and raised - the socialist person.

[...] In our country, every constructor of socialism is faced with responsibilities which are difficult to manage only from one's own experience. How many times does Soviet literature help him!23 (Novicov 1951: 198) 
Novicov goes on to list several books whose characters exemplify the correct attitudes toward socialist projects. His strongest claim, with an almost unbearable irony, is that the heroes of the Soviet novel Far from Moscow demonstrate not just correct attitudes but the correct work methods that were put to use in the Danube-Black Sea Canal. This project, "one of the Soviet bloc's most notorious postwar symbols of Stalinist repression," was in essence a forced-labor prison camp (Levy 2001: 88). Thousands of political prisoners were worked to death from 1949 to 1953, digging only three of the 75 kilometers planned. This "remarkable instance of the irrational use of violence," in Stephen Jowitt's description, was a political failure as well:

In the first place the regime made very little if any attempt to resocialize the political prisoners; it was a strictly coercive undertaking. And as a symbolic endeavor it brought only scorn from the people: it hardly fulfilled the elite's promises of achievement, and it was too obviously associated with Soviet demands [...]. (Jowitt 1971: 100)

A foreignized discourse of translations leads to a labor camp, also marked as foreign. The extent of this failure is demonstrated by the fact that even the Romanian Party eventually expresses regret, even for the literature extolling the Canal. The first novel by Petru Dumnitriu (future head of ESPLA), Road without Dust, a socialist realist depiction of the virtues of work on the canal, was published the same year as Novicov's statement above. By 1958, after the departure of the Soviet army, the novel is labeled unpublishable, and later, by Dumnitriu, a "sin" (Țugui 2001: 32). This example shows a correlation between the violence of the linguistic project and that of the larger modernization associated with Soviet colonization. The primary colonial purpose of translations of literature is to continue the work of all literature, that of transforming subjectivities from their pre-War decadence into modern Soviet-style citizens, technologically, historically, and geographically advanced members of society. We can call these citizens "foreignized."

\section{"Ich muß es anders übersetzen": resistance on state terms}

The question of resistance to this state project is perhaps the most complicated part of the Romanian case. While the difference between Gheorghiu-Dej and a worker at the Black Sea Canal is clear, the cultural-political position of a literary man in his twenties who finds the state press his only possible employment (I am thinking of Paul Celan) is less clear. For the purposes of this article, I will focus on those moments in which the state and its opponents, in effect, agree on the rules of engagement, in which those resisting the rhetoric of Sovietization see the foreignization of Romanian as an important problem and the production of literature as the key means of producing new Romanian subjectivity. I will focus this last section on those who, as the state does, treat the discourse and work of translation as the important position for engagement with cultural politics.

Ironically, given the great emphasis laid on the work of translators, Romania did not have enough specialists in Russian to meet the demand for translations. The diminutive number of Russian speakers made it difficult to accomplish the work of translation. As a result, The Russian Book and ESPLA often paired Russian specialists with a Romanian writer, called "the stylist." 24 This arrangement makes the state uncomfortable, because it distances the Romanian writer from the Russian language. 
Iordan himself argues that "our writers should learn Russian. ...the work of translation should be done by a single person, in the sense that the 'translator' and 'stylist' should be one and the same person" (Iordan 1954). ${ }^{25}$ The objectivity of this problem, and the official acknowledgement of this strategy, gives those who would resist the translation of Romania a toe-hold, a fissure in the edifice of the golden age. The writers are able to debate the relative culpability for the literary quality of the translation, whether the translator or the stylist should be held responsible for the representation of its content and for the clarity of its language. Those writers who associate the knowledge of Russian with an inferior Romanian product mount a kind of resistance to the process of translation. Two writers who stand out in this regard are Alexandru Philippide and the renowned Modernist poet and philosopher Lucian Blaga.

Philippide uses his post as editor of The Russian Book to take a strong stand, in the literary journal of the Romanian Writers Union, against Sovietized Romanian. Philippide works to emphasize the foreignness of the one who knows Russian and the diminished quality that results from his influence. Giving the example of a socialist realist novel (The Harvester, by Galina Nicolaeva), Philippide divides the labor of bringing over the ideological content from the literary:

The translator had, therefore, to render carefully this new way of thinking of the Soviet person, his permanently heroic attitude in vanquishing egoistic and individualistic impulses. The stylist focused on maintaining the author's stylistic personality. ${ }^{26}$ (Philippide 1952: 266)

While the Russophone translator works against individualist impulses, the Romanian stylizer ignores this ideological method and preserves exactly the personal style of the author. Philippine maintains this division throughout his article. On the one hand, the translator represents the wellspring of Soviet ideology in Romania. The stylist, on the other hand, has his origin in Romanian folk culture:

Stylizing means, in fact, making beautiful with the help of art. One can say of the patterns of a carpet or of a mottled pot that they are stylized, in the sense that the rustic craftsman who wove or glazed did not try to reproduce the flowers or birds for the rugs or pots, but rather he tried to extract the characteristic lines. This is stylization, the essential process of our popular arts. ${ }^{27}$ (Philippide 1952: 263)

The stylist brings greater inaccuracy to the translation, buffering the Romanian from the foreign, resisting the didactic purpose. And yet, Philippide is also able to blame the Russian speaker for this distance. Contrary to the line adopted by Iordan, Philippide argues that a serious impediment to the improvement of translations from Russian is the fact that the writers involved do not know Romanian well enough. He begins a long list of problems with this observation:

Writers who are to give literary, artistic form to a translated work are often faced with textual translations in a Romanian language which is not only non-literary, but has many elementary mistakes in grammar and in the use of words. ${ }^{28}$ (Philippide 1952: 262)

He goes on to list examples of these mistakes, explaining that each one "is not Romanian." 29 The end result of these influences is a translation "which falsifies the sense of the text, making it mistaken, or purely and simply making the phrase unintelligible" (267).$^{30}$ Philippide's attack on the work of the Russian-speaker gives voice to a rejection of the Soviet educational project. The translator's Russian makes the 
content of books of Soviet literature unintelligible. If Romanians do not learn the lessons of this literature, it is because it is not intelligibly written. Philippide finds a way to oppose the translation of Romanian and the transformation of Romania. Philippide finds a fissure where he can object to the translation project.

While Philippide was a literary figure before World War Two, neither he nor anyone else had Lucian Blaga's stature and influence. As a poet, Blaga defined modern, literary Romanian. When Philippide calls certain translations "non-literary" it is safe to say that, as poetry, he means "non-Blagan." As a philosopher, Blaga developed a model of national culture that placed metaphor at the center of a people's sensibility, a model which led him to agree, in these broad terms, with the state's belief that literature would shape the nature of the new Romania. He disagreed as to the definition of that culture. Blaga's importance can be measured by the fact that he is among the first to be attacked by the new regime. Just six months after the Soviet occupation began, the state newspaper quotes the Minister of Justice, Lucrețiu Pătrăşcanu, who accuses Blaga of being a "mystic with a vaguely medieval scent” who opposes "dialectical materialism...which will be, without doubt, the basis of thought systems and scholarship in the world of tomorrow" (Pătrăşcanu 1945). ${ }^{31}$ Blaga is treated harshly by the new regime, but not imprisoned. He is reassigned from his university chair to a position as library cataloger, and he is not allowed to publish any work, except translations.

This censorship has the inadvertent effect of investing Blaga's translation work with the cultural resonance of his pre-war philosophy and poetry. Blaga is the most important translator of this period, and his participation in the state translation effort brings that project great credibility, even as it allows him to re-assert his own importance. Blaga brings high-culture authority to the mostly Russian state translation project, even though he only translates a few poems from that language. Blaga's major translation of this period is from German: a complete version of Goethe's Faust, published in 1955. Both the translation and its reception show that Blaga and the state agree on the terms of debate: the foreignization of Romanian and the interpellation of the public into a cultural ideology.

Blaga agrees that the language of a translation has cultural political importance, and that Philippide is right to focus on the translator's Romanian style. Blaga's style of resistance is built on the kind of artistic approximation Philippide advocated. Recalling Novicov's assertion that "Soviet literature is the most advanced literature in the world today, in the first place because it mirrors the most advanced reality," we can understand the pointedness of Blaga's comment, in a 1956 public speech:

A poet who translates another poet is in no way capable of transforming himself into a perfect mirror of his object. This capacity is possible in the mechanical and physical world, but not in the complicated world of spiritual phenomena. ${ }^{32}$ (Muzeul Literaturii Române 25,381/11)

Blaga opposes the use of literary translations as technical manuals, challenging in this way the modernization rhetoric of the state translation project. Rather than focusing on the industrial lessons available in literature, one should study it for its Romanian qualities: "the most characteristic structures, inclinations, and stylistic ticks of a poet may be studied best of all in connection with the translations he writes" [emphasis in original]. ${ }^{33}$ Blaga's emphasis on "stylistic ticks" is not accidental; he is thinking of the translator-stylist structure at use in most of the state translation 
project. By calling attention to the role of the poet, that is, the Romanian-language specialist, Blaga recreates the translator-stylist structure, even though he works directly with the original. More strongly than Philippide, Blaga emphasizes the Romanian style of the translator as the key factor in reading a translation. Blaga advocates the Romanianness of the translation as a kind of resistance to foreignized translation.

It seems natural, then, that Blaga should make special use of the translation scene in the first part of Faust. Blaga marks this scene with a footnote, calling attention to Faust's undogmatic approach to translation. With Mephistopheles in the study disguised as a poodle, Faust attempts a series of translations of the Greek gospel of John, "In the beginning was the word." Under Faust's pen the line becomes, "In the beginning was the Sense," then, "In the beginning was the Power," then, "In the beginning was the Deed." This process so irritates Mephistopheles that he changes shape from poodle to scholar, and he scolds Faust for his abuse of the word. What Mephistopheles calls abuse is nothing more than the translator following his own reasoning through a series of German rhyming couplets:

\author{
Geschrieben steht: „Im Anfang war das Wort!” \\ Hier stock'ich schon! Wer hilft mir weiter fort? \\ Ich kann das Wort so hoch unmöglich schätzen, \\ Ich muß es anders übersetzen, \\ Wenn ich vom Geiste recht erleuchtet bin. \\ Geschrieben steht: Im Anfang war der Sinn. ${ }^{34}$ (Goethe 1999: 44)
}

Faust's inspiration to translate otherwise than the original („Ich muß es anders über-

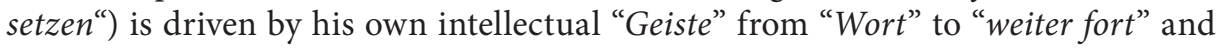
from "recht erleuchtet bin" to "der Sinn." That is, despite Faust's antagonism with the original, this passage moves from rhyme to rhyme, the language knitting itself together fluently. In a translation mis-en-abyme, Blaga repeats Faust's relationship to the Bible in his own relationship to Goethe. The climax of the scene, that which really irritates Mephistopheles, comes with the move from the third translation, "In the beginning was the Power" to the fourth, "In the beginning was the Deed." Faust makes this last change with the help of the spirit ("Mir hilft der Geist!"), a move Blaga presents with a very close Romanian rhyme:
Din ce adâncuri vine şoapta?
M-ajută duhul şi-mi dă sfat.
La început voi pune Fapta.
(Goethe 1955, trans. Blaga)
[From what depths comes the whisper?
The spirit helps me and gives me advice.
In the beginning I will put The Deed.]

In Romanian, the rhyme evokes a whisper from unidentified depths. This is not the intellectual Geist that helps Faust in German. The rhyme of a mysterious whisper with the Deed unsettles our confidence in the Deed. The authorial surety displayed in "I will put the Deed in the beginning" is belied by its connection to a source of mystery. In distancing the author from the deed of writing, Blaga distances the translator from the original text. This subtly antagonistic line introduces skepticism into the translator's relationship with the original. Blaga's image of tension between 
original and translation is not far removed from Philippide's model of the conflict of translator and stylist.

In this example, we see the literal practice of translation used within the cultural politics of translation as a metaphor. In using a rhyme to suggest that the translation lies over a mystery, Blaga uses fluency to insert a sense of conflict into the translation. This conflict is more apparent when we see that the line, "From what depths comes the whisper," is an interpolation, Blaga's own "anders übersetzen." Almost invisibly, he stages his words against Goethe's. This rhyme of "şoapta" and "fapta" is fluent; it allows his syntax to follow Romanian, not German. He does not stretch his language to remind us we are reading a translation; in fact, he accentuates the polish. When one section is rejected by the state editor without explanation, Blaga speculates that his text was "too good," too Romanian, not foreignized (Gruia 82). Blaga uses the translation scene in Faust to stage a larger conflict with the language and ideology of the new communist regime. Domestication is both the means and the end of his translation.

Blaga's Faust is the most enthusiastically received translation of this period. 25,000 copies of Faust were published. In Bucharest, the book was sold out in three days. In Cluj, Blaga's home, the shelves were clean within a few hours. The facts of this reception allow one reviewer to create a space for resistance, using the strategy of interpellation that Iordan describes. ${ }^{35}$ The reviewer draws attention to Blaga's importance through a strategic ellipsis, inviting an alternate reading to the one he gives:

The new Romanian version of "Faust," in Lucian Blaga's translation, has not reached the light of the show-case, because it sold out in the first two or three days after it appeared. It's understandable... Few books of world literature reflect a greater artistic richness, the issues and aspirations of an epoch of human history, as does the dramatic poem "Faust," Goethe's immortal masterpiece. ${ }^{36}$ (Florea-Rariste)

It is difficult to imagine a public so thirsty for the immortal work of Goethe, and so dissatisfied with the available versions, that a new translation would sell out so quickly on its merits alone. The ellipsis invites the reader to fill in the more probable, though unutterable, explanation that the public will throng to whatever Blaga publishes. It is the Romanian translator, not the foreign author, who drives the work's reception. The reviewer here duplicates the model of official speech that Iordan outlines. In the same way that an official "we" invites a public's "they," so does this ellipsis invite the public to fill in its own "understanding." This reading seems to have occurred to the new regime, as well. In an interview for state radio, Blaga mentions the remarkable sales figures, leading toward the same "it's understandable." The interviewer jumps in, anxious to fill the ellipsis with a counter-explanation: "The public has a great thirst for the classics" ${ }^{37}$ (L. Blaga 1960). Those listening to this broadcast must have been pleased by the interviewer's inadvertent confirmation of Blaga's stature.

The Romanian public is able to read the complicated positioning of translators such as Blaga. His most powerful use of the position of the translator comes in the 1956 public speech I have mentioned already, "Meetings with Goethe" (Muzeul literaturii române 25.381). In the process of giving his intellectual autobiography - a series of meetings with Goethe and German culture - Blaga argues the case of translation as resistance. Blaga states that he published his first philosophical essay by calling it 
a translation. He tells this story with an ironic reference to the State's (by now longstanding) accusation that Blaga is a "mystic with a vaguely medieval scent":

This was my first attempt at philosophy that made a place for itself in our press. Why did I turn to a "mystification?" In the atmosphere of philosophical ignorance that was master, then, of these parts of Transylvania, it seemed the only way for me to see my writing bloom in the printer's letters. ${ }^{38}(6)$

His reference to the "ignorance that was master, then" invites the public to complete the thought, "then, and now." Blaga wants his public to read him contextually. The emergence of "mysticism" is a result of ignorance, Blaga's response to a particular historical circumstance. The circumstance of the 1950s gives particular meaning to his characterization of the Faust translation. The conversation with the State publishing house that led to the translation seemed to Blaga "a lively clash of sabers," 39 that is, the beginning of a duel (8). In another loaded sentence, Blaga claims that he won this fight. "And to save a poem, in translation, a single victory of the translator over the author often suffices"40 (11). We have seen this antagonism with the author modeled in the translation scene above. Here, however, despite the immediate context, no one would read "the author" as Goethe. Just as in Tudor Vianu's article, "journey" can only mean a trip to the Soviet Union, so Blaga's statement can only refer to one author. Within the discourse of translation in Sovietized Romania, Blaga refers to the victory of the Romanian translator over the original, the victory of domestication that saves Romanian culture from Soviet foreignization.

The best evidence we have of the public's willingness to read Blaga's statements within the discourse of translation comes from a first-hand account of his speech. The same people who rushed to buy copies of Blaga's Faust came to this lecture in droves. Bazil Gruia, a Cluj doctor and friend of Blaga, reproduces photographs of the hall, with this description:

Taken just after the last person had left the hall, these photographs - in which one sees destroyed chairs and pieces of wood ripped out of the floorboards, as a result of the pressure of those in the corridor and on the stairs who wanted to enter the overflowing room - have the value of an exceptionally meaningful documentation of the immense prestige which the philosopher and poet enjoyed. ${ }^{41}$ (Gruia 1981: 21)

In the photos, one sees rows of chairs crushed on top of each other, shattered wood and twisted metal. This destruction demonstrates the potential power of Blaga's position, its viability as an alternative to Soviet foreignization. In fact, it is possible to claim that the work of translators like Blaga kept a space for a multidimensional Romanian culture open, even under political oppression. Once the political circumstances changed to allow cultural producers greater flexibility, they were able to make use of the materials these 1940s and 1950s translators had saved. The eventual changes to the State and the terms of engagement with the State result in complicated ebbs and flows in State control over translation and culture, including a fundamental shift away from Soviet control. Indeed, the Party would not sustain the intensity of this project in later decades, a fact which leads eventually to Blaga's rehabilitation and publication in 1963, which was, regrettably, two years after his death.

This article shows the logic of translation at work in power during the early communist period and one model of resistance. The case of 1950s Romania shows us the level of historical detail necessary for Translation Studies critics to read a discourse 
of translation. A reading of this period that did not approach the particular meaning of "foreign," for example, would mis-read the period and not account for Blaga's tactics. The argument I have made here also opens up the question of other models for translation beyond those current in Translation Studies. The Romanian case happens to intersect with the vocabularies of Anglo-American Translation Studies and Romanian cultural politics. We cannot assume, however, that all cases will be as hospitable. It is not my intention to suggest that we can do a better job of reading translation, simply by fine-tuning our pairs of foreign / domestic and hegemony / dissent. I hope, rather, that this example of the inverted relationship of those pairs will help to exhaust their appeal and will drive us toward new models of translation in culture. What would happen, for example, if we took translation itself as a model for culture? We could define culture then not on the basis of a momentary expression of hegemony but as a long-term process of redefinition, exhaustion, and recreation. We might find it useful to see the developing discipline of Translation Studies in this way, as a culture in which viewpoints foreign to each other interact through a constant process of translation. ${ }^{42}$ In this process, the sustained input of detailed studies of translation in various historical situations will take us out of those sets of terms that explain nothing so well as our own North American situation. In this sense, I suppose I come to a kind of agreement with Venuti. The problem we face is that our models - including The Translator's Invisibility - are too domestic, and they would benefit from a more flexible relationship with the foreign.

\section{NOTES}

1. "Soviet Colony" recognizes the usefullness of postcolonial studies in analysing those countries that were called "Soviet satellites." See David Chioni Moore, "Is the Post- in Postcolonial the Postin Post-Soviet? Toward a Global Postcolonial Critique," in Gaurav Desai and Supriya Nair (eds.), Postcolonialisms (NJ: Rutgers UP, 2005), 514-38 and Vladimir Tismăneanu, Stalinism for All Seasons: A Political History of Romanian Communism (Berkeley: University of California Press, 2003).

2. See the introductions to Sherry Simon and Paul St-Pierre, Changing the Terms: Translating in the Postcolonial Era (Perspectives on Translation; Ottawa: University of Ottawa Press, 2000) 305 and Maria Tymoczko and Edwin Gentzler, Translation and Power (Amherst: University of Massachusetts Press, 2002) xxviii, 244.

3. In addition to those books mentioned elsewhere in this article, see Lucian Boia, Miturile Comunismului Românesc (București: Nemira, 1997) 2 v., Dennis Deletant, Communist Terror in Romania: Gheorghiu-Dej and the Police State, 1948-1965 (London: Hurst \& Company, 1999) xii, 351, Robert Levy, Ana Pauker: The Rise and Fall of a Jewish Communist (Berkeley: University of California Press, 2001), Dan Pavel, Cine, Ce Si De Ce? (Bucharest: Polirom, 1998), Tismaneanu, Vladimir, Stalinism for All Seasons: a Political History of Romanian Communisim (Berkeley: University of California Press, 2003), Lidia Vianu, Censorship in Romania (Budapest: Central European University Press, 1998) x, 233.

4. Iorgu Iordan, Influențe Rusești Asupra Limbii Române (Analele Academiei Republicii Populare Române; Bucharest, Romania: Editura Academiei Republicii Populare Române, 1949). My analysis of foreignization in early Romanian communism is indebted to Katherine Verdery's analysis of nationalism in the Ceauşescu period. While she does not spend much time on Groza and Gheorgiu-Dej, her thesis that the discourse of later communism elevates the nation over the international suggests, by a logic of inversion, the dominence of the foreign in early communism. Her privileging of discourse is also important to this paper. "For a Party bent on transforming consciousness, control over language is one of the most vital requirements" (89). See Katherine Verdery, National Ideology under Socialism: Identity and Cultural Politics in Ceauşescu's Romania (Societies and Culture in East-Central Europe; Berkeley: University of California Press, 1991) xvi, 406. 
5. All uncredited translations are my own. The Romanian original reads: Situația va mai dura o bucată de vreme, până când cunoştințele de limbă rusă ale Românilor vor căpăta amploarea cantitativă şi calitativă care să-i facă apți a le utiliza curent şi sub aspectul lor vorbit, atât în relațiile dintre dânşii, cât şi, mai ales, în relațiile cu subiecte vorbitoare a căror limbă maternă este rusa.

6. Institutul de Lingvistică al Academiei R. P. R. Documents on this movement are reproduced in Gh. Buzatu and Mircea Chririțoiu, Agresiunea Comunismului În România: Documente Din Archivele Secrete 1944-1989 (1; Bucharest, Romania: Paideia, 1998), see also Pavel Țugui, Istoria Si Limba Româna În Vremea Lui Gheorghiu-Dej (Bucharest, Romania: Editura Ion Cristoiu, 1999) at 189-236.

7. narodnic <rus. нардник, care a fost tradus, pe vremuri, prin poporanist

8. Oamenii partidului nostru sunt luptători. Ei au mereu în vedere pe adversarii şi duşmanii clasei mucitoare de pretutindeni. Aceşti inamici sunt toteauna prezenți, dacă nu fiziceşte, ceea ce se întâmplă totuşi adesea, desigur prin acțiunea lor de fiecare moment, îndreptată contra intereselor permanente ale muncitorimii, ale oameilor cinstiți de oriunde. Acestă prezență continuă a duşmanului de clasă, exprimată lingvistic prin «voi» sau «ei» (chiar dacă aceste cuvinte nu apar niciodată în articol sau în cuvântare), duce inevitabil le deasa întrebuințare a lui noi, acolo unde, strict gramatical vorbind, acest pronume ar fi de prisos. Noi se apone, cu dârzenie şi violență, lui voi sau ei, şi frecventa lui apariție face impresia unei lovituri repetate dată adversarului.

9. Iată un exemplu foarte elocvent în acest sens: «Noi nu ne educăm tinererul în spiritul huliganismlui...» (Gh. Gheorghiu-Dej). După fiecare pasaj cu noi cititorului îi vine automat în minte voi sau ei, cu ajutorul cărora completează gândirea autorului, potrivit intențiilor acestuia: noi nu ne educăm tineretul ca voi (sau ca ei)....

10. Cartea Rusă.

11. The listings for 1952, 1953, and 1957 are incomplete. I have extrapolated from the available data, multiplying the per-month rate, to find the numbers above. This method gives a better picture of the total production, and does not change the ratio of translations to originals. It is important to note that the original language cannot always be determined by the title, as I have done here. I would guess that many of the translations from Korean or Chinese were written from Russian versions, but because I cannot be sure, I have not counted them here. As Thomas Amherst Perry has pointed out, even titles translated from the languages of speciality for the translator are sometimes from Russian, for example Leon Levitschi's translation of Mark Twain (Thomas Amherst Perry, Passage to Romania: American Literature in Romania (Iaşi, Romania; Portland, Or.: Center for Romanian Studies, 2001) 212 at 118. Also, Russian titles are sometimes translated from other languages, such as Arghezi's versions of Kârlov from French. For these reasons, the total number of translations makes a better comparison.

12. Îndeobşte traducerile preocupă scriitorii în epoca eroică a începuturilor

13. a luat un avânt deosebit, în condițiile revoluției culturale

14. Or, până la 23 august $1944 \ldots$ goana după un câştig cât mai mare - neiertătoarea lege economică fundementală a capitalismului - a fost în chip firesc şi lege fundamentală a editorului din România burgheză. Această lege a îndemnat pe editori să traducă în româneşte cu preferință şi în masă, tocmai perele cele mai decadente ale apusului....

15. Calea pe care s-a ajuns aproape fără excepție la o industrie a deșeurilor literare, în țările lumii capitaliste, unde marfa de calitate proastă a fost şi este prezentată sub etichete de-o strălucire ademenitoare, ca unele cutii de conserve reprezentînd o permanentă premejdie de intoxicație alimentară.

16. concepția negustorească despre traduceri şi apoi în necunoaşterea condițiilor pe care trebue [sic] să le îndeplinească un traducător şi implicit o traducere.

17. Editura de Stat pentru Literatura şi Arta

18. prin mijlocirea cărților, setei aprinse de cunoaştere a unor largi pături româneşti, care au astfel prilejul de a lua contact cu cultura țărilor progresiste şi în primul rând cu cultura bogată şi activă a Uniunii Sovietice.

19. au rolul de mare importanță de a educa întregul nostru popor muncitor în spiritul ideilor comuniste, de a-i înfățişa pilde mărețe de eroism şi de creație, de muncă avântată în slujba patriei, de patriotism şi de apărare a păcii, pilde care-l ajută în opera de contruire a socialismului în țara nostră.

20. o fetişancă de vreo 18 ani, care dirija singură un atelier întreg cu maşini ...Unde o mai întîlnisem? Abia tîrziu, mi-am amintit de traducerea apărută în «Littérature soviétique» a unei poezii de Scipaciov 
21. O traducere trebuie nu numai să apropie pe marii scriitori străini de noi, dar să ne apropie şi pe noi de lumea lor. O traducere măiestrită ne deschide perspective noi către o lume necunoscută, face să răsune în sufletul nostru coarde care n-au mai vibrat. O traducere trebuie să fie o călătorie într-o țară străină.

22. It is worth pausing to observe how Venuti fits into this discourse. Vianu is a Germanist by training, and it is likely that, in the passage quoted, he is recasting in Sovietized terms Freiderich Schleiermacher's "On the Different Methods of Translation." Venuti states there is "none so decisive” as Schleiermacher's formulation of the translator's two possibilities:

Schleiermacher allowed the translator to choose between a domesticating method, an ethnocentric reduction of the foreign text to target-language cultural values, bringing the author back home, and a foreignizing method, an ethnodeviant pressure on those values to register the linguistic and cultural difference of the foreign text, sending the reader abroad. (20)

Even though Vianu and Venuti write Schleiermacher into different contexts, they follow the same logic of translation. Both writers envision the power of the foreign to take the reader away from his home. My point is not to associate Venuti with the guilt of Soviet colonization, and so I need to make a careful distinction. Venuti, along with much progressive work in Cultural Studies, has a geneological connection to Marxism. The economic analysis that opens his book follows Marxist terms, for example his assertion that "Work-for-hire contracts alienate the translator from the product of his or her labor with remarkable finality" (10). He believes that language is fundamentally ideological and that new language practice can change the ideological consciousness of his readers. Overall, however, we have to say that he is indebted to other Marxist thinkers than those working in 1940s and 50s Romania. The alienation of labor is not a major trope of Romanian communism, and Venuti does not argue for a centralized, command economy. While Romanian communists agree on the identity of language, ideology, and political power, their ideal subject is (ostensibly) not a fragmented subject but a noble tractor driver. The central problem here is a problem of translation. Venuti presents his terms as though language and ideology were linked everywhere in the same way; Eastern Europe shows that the connection must be re-modelled. The excessive dogmatism of work like Venuti's leads us astray when we transfer these terms to Eastern Europe. Lawrence Venuti, The Translator's Invisibility: A History of Translation (London; New York: Routledge, 1995) xii, 353.

23. Între mijloacele prin care poporul nostru muncitor îşi însuşeşte şi valorifica exemplul Uniunii Sovietice, al oamenilor sovietici, un loc de cinste îl ocupă traducerile din literatura rusă şi din literatura sovietică. Literatura sovietică este azi cea mai înaintată literatură din lume, în primul rând pentrucă ea oglindeşte realitatea cea mai înaintata - realitatea socialistă. ...Literatura sovietică ne arată deasemenea cum, în focul acestei lupte [spre zările luminoase ale comunismului] s'a călit o nouă mentalitate, s'a născut şi a crescut un om nou, superior - omul socialist. ...In patria noastră se pun adesea în fața fiecărui constructor al socialismului sarcini, cărora cu greu li se poate răspunde numai pe baza experienței proprii. De câte ori cartea sovietică îl ajută să găsească soluții!

24. stilazatorul

25. Scriitorii noștri trebuie să se învețe limba rusă. ...în munca de traducere trebuie să intervină un singur om, în sensul ca «traducătorul» şi «stilizatorul» să fie una şi aceeaşi personă.

26. Traducătorul a trebuit deci să redea cu atenție acest nou fel de-a gândi al omului sovietic, de atitudinea lui permanent eroică în învingerea pornirilor egoiste, individualiste. Stilizatorul s'a preocupat să păstrează personalitatea stilistică a autoarei.

27. Stilizare înseamnă de fapt înfrumusețarea cu ajutorul artei. Se poate spune despre motivele decorative ale unui covor sau ale unei oale smălțuite că sunt stilizate, în sensul că meşterul rustic care țese sau smălțueşte nu vrea să reproducă florile şi păsările pentru covoare sau pentru oale, ci vrea să extragă liniile caracteristice. Aceaste este stilizarea propriu zisă, care este precedeul esențial al artei noastre populare.

28. În fața scritorilor care urmează să dea o formă literară, artistică operei traduse, se prezintă adeseori traduceri textuale într'o limbă românească nu numai neliterară, dar şi cu multe greşeli elementare de gramatică şi de utilizare a cuvintelor.

29. nu e românească

30. care falsifică sensul textului făcându-l echivoc sau pur şi simplu făcând fraza ininteligibilă

31. un mistic cu un vag parfum medieval.... materialismul dialectic... care va sta, fără îndoială, la baza sistemelor de gândire şi de cercetare ale lumii de mâine 
32 Un poet care traduce din alt poet, nu are în nici un fel posibilitatea de a se transforma în oglindă pură o obiectului său. Asemenea posibilități sunt date în lumea mecanică şi fizică, dar nu în lumea complexă a fenomenelor spirituale.

33. structurile, inclinările, ticurile stilistice cele mai caracteristice unui poet, pot fi studiate mai ales în legatură cu traducerile, ce el le face.

34. It is written: "In the beginning was the word!"/ Here I stop already. Who helps me forward?/ I cannot place the word so impossibly high, / I must translate it differently,/ if I am correctly illuminated by the spirit./ It is written: In the beginning was the meaning.

35. The fact that there is only one example in the official press does not dimish its importance; rather, the fact that there is any example at all in the official press demonstrates the extent of support for Blaga. This support did not go unnoticed by the regime. For a detailed account of secret police monitoring of Blaga's translations and the public's reaction, see Dorli Blaga and Ion Bălu, Blaga Supravegheat De Securitate (Cluj: Biblioteca Apostrof, 1999).

36. Noua versiune romînească a lui „Faust," in traducerea lui Lucian Blaga, n-a ajuns să vadă lumina vitrinelor, căci a epuizat în primele două-trei zile de la apariție. E şi explicabil... Puține sînt cărțile din literatura universală care să reflecte cu mai mare bogăție artistică, frămîntările şi năzuințele unei epoci din istoria omenirii ca poemul dramatic „Faust,” nemuritoarea capodoperă a lui Goethe.

37. Publicul are o mare sete de clasici.

38. Aceasta era întîia mea încercare filosofică, ce-şi făcu loc în publicistica noastră. Dece am recurs la o "mistificare"? In atmostfera de ignoranță filosofică stăpînitoare, atunci, pe meleagurile ardelene, aceasta mi se părea singur care de a-mi vedea scrisul înflorind în litera tiparului.

39. o încrucişare jucăuşă de spade

40. Şi pentru a salva o poezie, în traducere, e de multe ori suficientă o singură biruință a traducătorului asupra autorului.

41. Executate imediat după ce ultimul om a părăsit sala de conferințe, fotografile acestea în care se văd scaune distruse şi piese de parchet smulse din pardoealsă, în urma presiunii celor care de pe coridoare şi scări voiau să intre într-o sală plină până la refuz, consider că au valoarea unui document deosebit de semnificativ pentru imensul presigiu de care se bucura deopotrivă filozoful şi poetul.

42. Here I find myself echoing a call Maria Tymoczko made recently in this journal, for "the internationalization of Translation Studies." I believe, and the case of Romania demonstrates, that she may underestimate the possibility of Western examples to change our intellectual assumptions. Maria Tymoczko, "Trajectories of Research in Translation Studies," Meta 50-4 (December 2005): 1082-1097.

\section{REFERENCES}

Anonymous (1945): "Problema traducerilor," Scânteia 2-294.

Anonymous (1954a): “În legătură cu problema traducerilor," Viața românească 7-8, pp. 218230.

Anonymous (1954b): “Concluzii la discuția asupra traducerilor literare," Veac nou 10-39.

BlAGA, D. and I. BĂLU (1999): Blaga supravegheat de Securitate, Cluj, Biblioteca Apostrof.

Vorbeşte Lucian Blaga (1960) (Radio interview, 1956 or 1957 in Cluj).

BoiA, L. (1997): Miturile comunismului românesc, București, Nemira.

Botez, D. (1954): “În problema traducerilor," Veac nou 10-30, p. 2.

Buzatu, Gh. and M. Chririțoiu (1998): Agresiunea comunismului în România: Documente din archivele secrete 1944-1989 1, Bucharest, Paideia.

Deletant, D. (1999): Communist Terror in Romania: Gheorghiu-Dej and the Police State, 19481965, London, Hurst and Company.

Goethe, J. W. von (1955): Faust, trans. Blaga, L., Bucharest, ESPLA.

Goethe, J. W. von (1999): Faust, ed. Trunz, E., München, Verlag C. H. Beck.

Gruia, B. (1981): Blaga inedit: efigii documentare 2, Cluj-Napoca, Editura Dacia.

IORDAN, I. (1949): Influențe rusești asupra limbii române, Analele Academiei Republicii Populare Române, Bucharest, Editura Academiei Republicii Populare Române.

IORDAN, I. (1954): “Limba traducerilor," Veac nou 10-35, p 2. 
Jowitт, K. (1971): Revolutionary Breakthroughs and National Development; The Case of Romania, 1944-1965, Berkeley, University of California Press.

Levy, R. (2001): Ana Pauker: The Rise and Fall of a Jewish Communist, Berkeley, University of California Press.

Moore, D. C. (2005): "Is the Post- in Postcolonial the Post- in Post-Soviet? Toward a Global Postcolonial Critique," in Desai, G. and S. NaIr (eds.), Postcolonialisms, Rutgers UP, pp. 514-538.

Novicov, M. (1951): “Pentru continua imbunătățire a caltății traducerilor," Viața românească 4-7, pp. 198-216.

PĂtrăşCANU, L. (1945): “Curente şi tendințe în filosofia romanească," Scînteia 2-115.

Pavel, D. (1998): Cine, ce si de ce?, Bucharest, Polirom.

Perry, T. A. (2001): Passage to Romania: American literature in Romania, Iaşi/Portland, Center for Romanian Studies.

Petrescu, C. (1954): “Traducerile şi arta traducătorului,” Veac nou 10-20.

Philippide, A. (1952): “Traducerile de proză din limba rusă,” Viața românească 5-5, pp. 261269.

Porumbacu, V. (1954): “Tălmăcindu-l pe Scipaciov,” Viața românească 7-7, pp. 357-361.

Simon, S. and P. St-Pierre (2000): Changing the Terms: Translating in the Postcolonial Era, Ottawa, University of Ottawa Press.

Tismăneanu, V. (2003): Stalinism for All Seasons: A Political History of Romanian Communism, Berkeley, University of California Press.

ȚUgui, P. (1999): Istoria si limba româna în vremea lui Gheorghiu-Dej, Bucharest, Editura Ion Cristoiu.

Țugui, P. (2001): Tinerețea lui Petru Dumitriu, Cluj-Napoca, Editura Dacia.

Tyмoсzкo, M. and E. Gentzler (2002): Translation and Power, Amherst, University of Massachusetts Press.

Venuti, L. (1995): The Translator's Invisibility: A History of Translation, London/New York, Routledge.

Verdery, K. (1991): National Ideology under Socialism: Identity and Cultural Politics in Ceauşescu's Romania, Societies and Culture in East-Central Europe, Berkeley, University of California Press.

Vianu, L. (1998): Censorship in Romania, Budapest, Central European University Press.

VIANU, T. (1956): Literatură universală și literatură națională, Bucharest, Editura de stat pentru literatură şi artă. 